Cahiers $d u$ MONDE RUSSE

\section{Cahiers du monde russe}

Russie - Empire russe - Union soviétique et États indépendants

$56 / 4 \mid 2015$

Médiateurs d'empire en Asie centrale (1820-1928)

\title{
Heather D. Dehaan, Stalinist City Planning, Professionals, Performance, and Power
}

\section{Martin Kohlrausch}

\section{(2)enEdition}

\section{Journals}

Electronic version

URL: http://journals.openedition.org/monderusse/8268

DOI: $10.4000 /$ monderusse. 8268

ISSN: $1777-5388$

\section{Publisher}

Éditions de l'EHESS

\section{Printed version}

Date of publication: 1 October 2015

Number of pages: $876-879$

ISBN: 978-2-7132-2507-9

ISSN: $1252-6576$

Electronic reference

Martin Kohlrausch, « Heather D. Dehaan, Stalinist City Planning, Professionals, Performance, and Power », Cahiers du monde russe [Online], 56/4 | 2015, Online since 01 October 2015, Connection on 25 September 2020. URL : http://journals.openedition.org/monderusse/8268 ; DOI : https://doi.org/ 10.4000/monderusse.8268

This text was automatically generated on 25 September 2020. 


\title{
Heather D. Dehaan, Stalinist City Planning, Professionals, Performance, and Power
}

\author{
Martin Kohlrausch
}

\section{REFERENCES}

Heather D. DEHAAN, Stalinist City Planning, Professionals, Performance, and Power, Toronto : University of Toronto Press, 2013, 272 p.

1 Heather DeHaan's book, entitled Stalinist City Planning, is at first glance "only" a case study of Nizhnii Novgorod. At second glance, however, it delivers exactly what the title promises - not in the sense of an encompassing survey but as a well-chosen approach which enables the author to present a deep-cutting and multifaceted analysis of the functioning of city planning and planning in general in the Stalinist Soviet Union.

2 This achievement is partially due to the fact that Nizhnii Novgorod, which had a strong industrial base and was thus greatly affected by the introduction of the first five-year plan, offers numerous insights into the complexities and dynamics of socialist urban planning. But, as DeHaan stresses, it is also due to the fact that at the time, the overarching planning ambition of the newly introduced Socialism was that the story of Nizhnii Novgorod should share general lines with most Soviet cities. Yet, it is foremost the meticulous, sharp and original analysis which DeHaan applies to her subject that lifts this study far above a case study.

3 Throughout her study, DeHaan connects her findings on Nizhnii Novgorod to the general developments in the Soviet Union, e.g., shifts in Stalin's political agenda, but also draws on recent findings in the histories of planning and experts. This works particularly when she focuses on the planner Alexander Platonovich Ivanitskii. Ivanitskii came to Nizhnii Novgorod to put through the urban planning indicated in the five-year plan. He kept his ties with Moscow and also played an important role for 
urbanism and the training of urbanists in the Soviet Union. Educated before the First World War, Ivanitskii believed that a scientific approach was the key to both solving concrete urban problems and mediating potential conflicts with the political decision makers. At the same time, he was perfectly prepared to embark on the vision of a socialist society as long as it would let him create the leeway necessary to put through his plans.

4 Next to embodying "scientific objectivism" as a member of the planning elite, Ivanitskii, as DeHaan makes clear, derived his power from two other factors: (1) the fact that urbanism was key to the Soviet project of actually building socialism and (2) the extreme urbanistic challenge of rapidly industrializing a city with insufficient urban infrastructure. When Nizhnii Novgorod was renamed Gorky in 1932, it acquired high symbolical relevance for the implementation of the new Soviet model. This also meant dealing with the legacies of imperial Russia and integrating older spatial structures as well as older loyalties and beliefs. More than once, as DeHaan shows for numerous telling conflicts, older spatial structures carried such meaning that they could not be changed as easily as the new socialist decision makers had expected.

In analyzing Ivanitskii's achievements and failures, DeHaan comes to a number of noteworthy and new results. First, she is able to portray two cohorts of Soviet planners in depth and with clear contours. The senior group, personalized by Ivanitskii, welcomed the opportunities of the new era even if its members were not convinced Bolsheviks. These planners saw and partially grasped the chance to have the state apparatus at their disposal and make use of property and real estate that had hitherto been in private hands. The use of urban change to create new societies could also combine with the planners' ethos. But these planners shared a very clear understanding of what could be achieved within the framework of a five-year plan, and, what is more, understood that planning was a complex mechanism situated between the political and the scientific level. In a convincing metaphor inspired by the fact that the planners ascribed needs to citizens, DeHaan compares them to "omniscient narrators of a novel."

6 The numerous problems these planners faced on the ground stemmed less from a lack of expertise or manpower than from the constant lack of resources, local opposition and ambiguous communications from Moscow. With the example of the so-called star-city plan, which DeHaan discusses at some length, the diverging local and central state interests, the constant underfunding of planners, and Ivanitskii's ability to use scientific ethos and pragmatism to meet the political demands of the party are well illustrated.

7 Within the brief period covered by DeHaan, however, a noteworthy transformation took place in the group of planning experts with the emergence of a new class of Soviet professionals. More and more planners evoked science as a neutral arbiter to postpone any action-as more research was allegedly needed-and thus avoided taking a position in the increasingly repressive political climate of the 1930s. However, as DeHaan shows, this position brought politics in and thus indirectly politicized science. DeHaan provides ample evidence of how the older values of professional knowledge and scientific universalism gave way to the new identity of a younger generation. Unlike their elders, the new planners, educated in Soviet times, did not embrace the ideology of the new Soviet state for pragmatic and instrumental reasons. In this, they responded to the growing uneasiness in the communist party. Only the younger experts had the 
credibility of being educated in the Bolshevik spirit. And they were able to respond to the party's wish for a more radical and more socialist class of professionals-the "praktiki." This was felt directly in Nizhnii Novgorod with the planner Nikolai Alekseevich Solofnenko. Solofnenko's impact was based on a new, undeclared deal with the Soviet system. Building on Stalin's self-description as "the architect of socialism," the younger planners now joined forces with the system in performing socialism in the urban sphere rather than putting through scientific planning principles. In a certain sense, as DeHaan shows, this was a way of acknowledging the shortcomings on the grounds of allegedly scientifically based planning and stressed the staging rather than building of socialism. This, on the surface, included participatory elements as these planners called on the citizens to legitimize action. While planners tried to transform citizens into 'cultured' urban dwellers through engaging them in the process of planning, city planning became a source of rights for the citizens.

The theatre metaphors that DeHaan uses throughout her study are mostly convincing as they capture the symbolic meaning of what was at stake: "the drama of building socialism," a drama larger than the citizens and planners alike. Cityscape both facilitated and resisted Soviet power, but clearly the city was the decisive set where the new political system had to prove its workability and eventually, legitimacy. DeHaan does not fall prey to describing the planners of both cohorts as almighty "demiurges" using the authority that the state bestowed upon them. Rather, she demonstrates how these planners had to function in and were often victims of an all-encompassing political system that lacked the very consistency which it claimed under the heading of socialism.

DeHaan describes how the establishment of a new planning logic under socialism and in the dynamics of the developing socialist state translated into new realities. She presents telling examples and analyses of how abstract representation of the socialist order in the city became a substitute for not having realized a true socialist order, but also for the socialist city that was never built. More and more, the city turned into a stage for Stalin's power. While this gave central place to the planners, DeHaan describes it as a Faustian pact, whereby planners depended on political patronage more than ever. Tellingly, after Stalin's death, engineers replaced the planners in the central function they held until the early 1950s.

DeHaan's work brings to the fore the mechanisms of how experts profited from the enormous tasks set by the socialist project and became more and more dependent on the political trajectories of this project. The planners' dream of a "plan that might represent and realize fixed, stable power that lay beyond contestation" was confronted with both the hardly consistent wielding of power in Moscow, the enormous inefficiencies and the subsequent economic crises felt in Nizhnii Novgorod. It is symptomatic that many of the plans, in particular the grandiose schemes of the "red planner" Solofnenko, remained impressive only on paper, while American specialists from Ford and other companies deeply transformed Nizhnii Novgorod in the context of US investment and disposal of experts.

11 All in all, DeHaan's excellent study represents a most welcome contribution to a field which is of great relevance both to the history of planning and urbanism, and of the critical phase of the establishment of a socialist society in the Soviet Union. DeHaan indeed delivers a history of Stalinist city planning and a new interpretation of planning under socialism in general. This is not a simple story of the mechanics of power versus 
resistance from below, but rather an unfolding of how planning partially scripted citizens' lives and was at the same time itself constantly changing forms against the realities on the ground. Rarely before have we come so close to what planning actually meant for the urban reality of the Soviet Union in the 1930s. At the same time, DeHaan presents a story of 'building socialism' in both the concrete and metaphorical sense. For all these reasons, her results are of great relevance not only for historians of the Soviet Union but for anyone interested in the role of planning, urbanism and in particular the ambivalence and multilayered dependencies of experts.

\section{AUTHORS}

MARTIN KOHLRAUSCH

KU Leuven 